УДК 378.016:811.161.2’243:81’36

DOI https://doi.org/10.32782/apv/2021.5.16

Надія МАКСИМЕНКО

викладач, Полтавський держсавний медичний університет, вул. Шевченка, 23, м. Полтава, Украӥна, 36011

ORCID: 0000-0001-5880-9505

Бібліографічний опис статті: Максименко, Н. (2021) Граматичні навички в сучасному вивченні української мови як іноземної. Acta Paedagogica Volynienses, 5, 106-111, doi: https://doi.org/10.32782/apv/2021.5.16

\title{
МІСЦЕ ГРАМАТИКИ У ВИВЧЕННІ УКРАЇНСЬКОЇ МОВИ ЯК ІНОЗЕМНОЇ НА ПОЧАТКОВОМУ ЕТАПІ
}

У статті розглядається проблема оволодіння засобами комунікації за допомогою граматичних навичок у процесі навчання іноземних громадян на початковому етапі в навчально-науковому центрі. Метою статті є обтрунтування практичного застосування граматичних основ української мови для систематичного оволодіння мовою іноземними здобувачами. Досліджуються методичні засоби і форми презентації, закріплення та активізації національно-культурної семантики на мовних заняттях, з метою пізнання іноземними слухачами украӥнських культурних цінностей у контексті лінгвокраїнознавства. Звертається увага на свідомо-практичний метод навчання, який полягає у планомірному формуванні у слухачів системи сприйняття, розуміння й оволодіння мови, яка повинна відповідати правильній архітектонічі української мови. Доводиться необхідність помірного використання теоретичного матеріалу, зокрема, на активізацію комунікативного принцииу навчання та взаємозв'язок усіх компонентів навчання з граматичним матеріалом, розумне використання опори на рідну мову, помірковану систему вправ для відпраџювання граматичних навичок, адже системне бачення мови дає поштовх до формування мовної особистості. У статті вміщено оцінки мовознавців різних наукових шкіл щзодо формування граматичних навичок, аналіз яких дозволяє знайти баланс між надмірною граматикалізацією навчального прочесу. Демонструються приклади формування граматичних навичок як найголовнішої частини комунікативної компетенції, зокрема використання індуктивного методу (від поодинокого до загального). Розроблено системи вправ, спрямовані на розвиток фонетико-граматичних навичок, володіння усною формою мовлення в межах комунікативних потреб іноземних студентів, щзо значно покрашує рівень володіння украйнською мовою здобувачів освіти, навіть тих, які далі будуть навчатись англійською мовою в Украӥні й українська мова їм буде потрібна тільки на рівні комунікування.

Ключові слова: граматика, граматичний аспект, граматична навичка, комунікативна компетентність, свідомо-практичний метод, індуктивний метод, модель мови.

\section{Nadiya MAKSYMENKO}

Lecturer, Poltava State Medical University, Shevchenko Str., 23, Poltava, Ukraine, 36011

ORCID: 0000-0001-5880-9505

To cite this article: Maksymenko, N. (2021)Hramatychninavychky v suchasnomu vyvchenniukrainskoi movy yak inozemnoi [Grammatical skills in the modern study of the Ukrainian language as a foreign language]. Acta Paedagogica Volynienses, 5, 106-111, doi: https://doi.org/10.32782/apv/2021.5.16

\section{THE PLACE OF THE GRAMMAR IN THE STUDY OF UKRAINIAN AS A FOREIGN LANGUAGE AT THE PREPARATORY STAGE}

The problems of communication skills in the process of teaching foreign citizens at the initial stage in the educational and scientific center are discussed in the article. The purpose of the article is to substantiate the practical application of the grammatical foundations of the Ukrainian language for the systematic mastery of the language by foreign learners. Methodological means and forms of presentation, consolidation and activation of national-cultural semantics in language classes are studied in order to acquaint foreign students with Ukrainian cultural values in the context of linguistics. Attention is paid to the conscious-practical method of teaching, which consists in the systematic formation of students' system of perception, understanding and mastery of the language, which must correspond to the correct architecture of the Ukrainian language. There is a need for moderate use of theoretical material, in particular to enhance the communicative principle of learning and the relationship of all components of learning with grammar material, 
reasonable use of native language, moderate system of exercises to practice grammar skills, because a systematic vision of language gives impetus to language. The article contains assessments of linguists from different scientific schools on the formation of grammar skills, the analysis of which allows to find a balance between excessive grammaticalization of the educational process. Examples of the formation of grammatical skills as the most important part of communicative competence, in particular the use of the inductive method (from single to general) is demonstrated. Developed systems of exercises aimed at developing phonetic and grammatical skills, knowledge of oral speech within the communicative needs of foreign students, which significantly improves the level of Ukrainian language proficiency of students, even those who will later study in English in Ukraine and the Ukrainian language will be needed only at the level of communication.

Key words: grammar, grammatical aspect, grammatical skill, communicative competence, conscious-practical method, inductive method, language model.

Постановка проблеми. Під час навчання української мови іноземних слухачів особливе значення має врахування їхньої рідної мови як у презентації граматичного матеріалу, так і у формуванні мовних навичок і вмінь. Оптимальні засоби корекції вже набутих навичок і формування нових $є$ основною метою під час навчання іноземної мови. Іноземні слухачі, що вивчають українську мову, виявляють зацікавленість до економіки, науки, культури, громадського устрою, минулого та теперішнього країни. Навчання мови дозволяє іноземним слухачам осягнути духовне багатство, яке зберігається в мові, та зрозуміти нову для них національну культуру. Не можна успішно оволодіти іноземною мовою, якщо не зрозуміти духовну і моральну культуру носія мови. Різниця в національних характерах, у ступені готовності до контакту, у формах вираження емоцій є причиною непорозуміння, що ускладнює процес навчання. На початковому етапі спілкування гостро постає проблема виховання толерантності, поваги до чужої культури, мови, подолання роздратування від несхожості культур. I.O. Ільїн відзначав: «Дуже важко подолати природну, наївну і дуже шкідливу впевненість у тому, що своє - єдине вірне, а все чуже у кращому випадку смішне» (Ільїн, 1993: 200). Мовний бар'єр помітніший, а бар'єр культур відчувається тільки під час зіткнення рідної культури з чужою.

3 перших занять у навчально-науковому центрі з підготовки іноземних громадян Полтавського державного медичного університету починається знайомство слухачів з українською мовою і новим для них соціальним і культурним середовищем. Це підвищує мотивацію до вивчення мови, допомагає психологічній і соціальній адаптації, стимулює всі види мовленнєвої діяльності, пом'якшує культурний шок. Мова як складова частина культури допомагає входженню іноземних слухачів в українське національне середовище. Знання тільки одиниць мови недостатньо для оволодіння нею як засобом спілкування. 3 перших днів навчання в групі повинен домінувати принцип психологічної комфортності. Взаєморозуміння, терпимість, повага до культури, партнерство в комунікації - головні умови ефективності навчання. Під час знайомства іноземних слухачів з українською культурою викладач мови стає головним провідником до ії̈ світу. Для правильного спілкування в групі потрібні гарні взаємовідносини, викладач повинен знати і поважати головні цінності рідної культури слухачів.

Варто зазначити, що в навчально-науковому центрі з підготовки іноземних громадян іноземні слухачі опановують мову як систему, основу якої становить граматика. За останні роки багато іноземних громадян вибирають вивчення української мови на рівні виживання, а не для подальшої фахової підготовки. Виникає питання - чи потрібна граматика тим слухачам, які навчаються на курсах вивчення української мови. Перед викладачами не постає питання, навіщо вивчати граматику, тому що, коли чуєш фрази: «Ти любиш я» або «Марія любиш Петро», стає зрозумілим, що без знання граматики спілкування ускладнюється. У цьому сенсі метою статті $€$ обгрунтування необхідності вивчення граматики на початковому етапі навчання іноземній мові незалежно від типу навчання. Письменник В. Набоков, коли проводив заняття 3 російської мови для початківців у коледжі Велса, переконався, що починати викладання мови треба $з$ граматики, а не $з$ лексики: «Анатомія повинна передувати систематиці, й вивчати поведінку слова набагато важливіше, ніж навчитись вимовляти російською «до побачення» або «добрий ранок»»» (Набоков, 2004: 97).

Аналіз останніх досліджень і публікацій. Дослідження процесів формування в іноземних громадян, що вивчають українську мову, граматичної компетенції здійснюється у працях 
М. Вятютнєва, І. Біма, Є. Пассова, С. Савиньон, С. Соколової, О. Тростинської, Н. Хомського та ін. Практичні форми роботи під час вивчення граматики досліджували В. Вінницька, 3. Мацюк, Н. Плющ та ін. Проте існує багато аспектів, які вимагають теоретичного осмислення та практичного застосування. Загальновідомо, що фундаментом під час вивчення української мови має бути граматика, тому що без неї всі мовні «поверхи»: аудіювання, говоріння, письмо, читання будуть неефективними.

Виклад основного матеріалу. 3 перших занять паралельно з вивченням літер та абетки української мови викладач знайомить іноземних слухачів 3 граматичними категоріями. У першому модулі знайомимо з поняттям роду (він, вона, воно) і пропонуємо запам'ятати закінчення на приголосний, на -а , на -о з винятками. Демонстрація функціонування категорії роду сприймається охоче, якщо лексичні одиниці дібрані відповідно до комунікативних потреб. Не варто із самого початку навантажувати пам'ять слухачів великою кількістю лінгвістичних термінів, треба використовувати під час пояснення, де можливо, переклад на рідну мову або описово фіксувати особливості граматичного явища. Опора на рідну мову слухачів не завжди можлива, оскільки слухачі знають мову емпірично і не знайомі з термінологією граматики своєї рідної мови, тому під час вивчення багатьох граматичних тем націлення на національно-орієнтоване викладання теоретичного матеріалу не приносить очікуваних результатів.

Крім того, якщо зосереджуватися лише на граматичних паралелях двох мов у навчальному колективі більш підготовлених студентів, отримуємо цікавий і неочікуваний ефект - слухач перекладає фрази 3 рідної мови подумки на українську, і навпаки. Таким чином, під час вивчення граматичного аспекту мови викладач звертає увагу на деякі моменти: помірне використання теоретичного матеріалу, щоб комунікативний принцип навчання не був у збитку; взаємозв' язок усіх компонентів уроку з вивченим граматичним матеріалом; розумне використання опори для відпрацювання граматичних навичок.

У другому модулі слухачі знайомляться 3 присвійними займенниками (мій, моя, моє), а в четвертому модулі - 3 категорією однини i множини іменників. Отже, вже на початковому етапі навчання іноземні слухачі опанову- ють граматику, що дає позитивні результати під час перших спроб спілкування.

Коли іноземні слухачі закінчують вивчати абетку та мають змогу написати букви, вони вже знайомі з частинами мови (зазвичай не знаючи цього терміна) - іменниками, займенниками (особовими, присвійними, вказівними), прикметниками, дієсловами, прислівниками i прийменниками. Звичайно, ці знання початкові, але вже є на що спиратися в подальшому вивченні граматики.

Вивчення іноземної мови - складний у психологічному сенсі процес, який вимагає змін у звичайних стереотипах мислення, він не складається 3 простого вивчення слів та правил. Мислення людини пов'язано з його рідною мовою. Вивчаючи нерідну мову, за словами Л.В. Щерби, «ми розбиваємо ілюзію, до якої нас привчає знання тільки однієї мови, ілюзію, нібито існують непорушні поняття, які однакові для всіх часів і народів. У результаті відбувається звільнення думки 3 полону слова, 3 полону мови і надання ій істинної діалектичної наочності» (Щерба, 1974: 536).

Головним у процесі викладання української мови як іноземної є свідомо-практичний метод навчання. Він вимагає від викладача вправного поєднання викладання теоретичних засад 3 формуванням комунікативних компетенцій слухачів. Викладач має усвідомлювати, що він формує на початковому етапі навчання гармонійну систему мови, переконує слухачів у тому, що українська мова не $\epsilon$ хаотичним застосуванням закінчень, суфіксів і префіксів. Тільки від викладача залежить, чи буде система, сформована на заняттях з української мови як іноземної, відповідати істинній архітектоніці української мови. Керуючись свідомо практичним методом навчання, будуємо роботу над формуванням граматичних навичок поетапно, логічно пов'язуючи явища, які презентуються, таким чином, щоб сформувати у слухачів системне бачення мови. Необхідно окреслити кордони мови і подивитись на мову наче відсторонено. Так вважають І.М. Пулькіна, Г.І. Рожкова, М.В. Всеволодова, Ю.М. Лотман. Сформувати у слухачів думку, що тепер немає того, чого б ти не знав, викликати відчуття закінченості навчання, досить складно. Безмежність мови лякає, викликає тривогу, яка заважає спілкуванню. Дотримуючись постулату, що кожна 
людина, яка вивчає іноземну мову, повинна отримувати відчуття задоволення, що вона може говорити цією мовою, викладач створює відповідні ситуації, наближені до реальних.

Академік О.М. Пєшковський назвав граматику «служницею всіх мовних навичок». Мовленнєва навичка створюється передовсім в умовах мови. А щоб брати участь у мовленні, діє така аксіома: хочеш говорити - говори. Для оволодіння граматикою іноземної мови потрібні навички. Щоб отримати хоч одну граматичну навичку, треба повторити одну граматичну одиницю в різних структурах не менше 15-ти разів, як вважає більшість фахівців.

Формування граматичних навичок - одна 3 найважливіших частин оволодіння комунікативною компетенцією. Так, наприклад, за 8, 6 та навіть 3 місяці до автоматизму відпрацьовується граматична навичка правильного вживання й узгодження прикметників і займенників 3 іменниками. Незалежно від того, знає слухач значення слова чи ні, якщо це слово відповідає на питання хто? або що? і закінчується на приголосний - це, звичайно, він (чоловічій рід); якщо ж закінчується на -a, то це зазвичай вона (жіночій рід).

Існує багато наукових теорій, які показують, як відбувається оволодіння мовою. Психолог Л. Виготський порівнював цей процес із хмарою, яка проллється зливою слів, словосполучень i, як кінцевий результат, речень (Виготский, 1996, с. 400). Доцільно згадати процес моделювання мови під час формування граматичних навичок за теорією Ноама Чомскі, коли «знання обмеженого числа моделей під час вивчення нової мови забезпечує ії безмежність» (Чомски, 1972: 100).

Звичайно, перш за все це стосується рідної мови людини, але навіть знання обмеженої кількості моделей іноземної мови може допомогти формуванню граматичних навичок цієї іноземної мови, що є найголовнішою метою оволодіння граматичною компетенцією.

Граматична навичка - це автоматичний елемент несвідомої дії. «Граматика не дається нам у реальних відчуттях, тому нам так складно вхопити ऑï», - писав Л.В. Щерба (Щерба, 1974: 23). Викладач повинен створити умови для бажання говорити іноземною мовою. У XIX ст. К.Д. Ушинський бачив у цьому переваги вчителя. На заняттях 3 мови як іноземної викладач перетворюється на артиста, на творчу особистість, і це дає гарні результати.

Повноцінне формування граматичних навичок - один із найважливіших аспектів у досягненні мети викладання мови на початковому етапі навчання іноземних громадян. «Сутність навички полягає в тому, що форма, яка сприймається автоматично, викликає у свідомості людини їі функцію, а необхідна функція автоматично викликає відповідну форму» (Капітонова, 2006: 135) - це положення методики викладання мови як іноземної є відправним для викладача в пошуках засобів для формування граматичних навичок у кожному конкретному випадку.

Найголовнішим аспектом методичної проблеми презентації граматичного матеріалу $\epsilon$ вміння викладача знайти баланс між наднормовою граматикалізацією навчального процесу: розмитістю граматики як такої в прагненні досягнути комунікативного ефекту. На початковому етапі навчання майже кожне заняття $\epsilon$ комбінованим, в якому наявні, з одного боку, повторення, подача нового матеріалу, його закріплення, відпрацювання, 3 іншого боку всі види комунікативної діяльності: говоріння, письмо, читання. На наш погляд, усі елементи заняття повинні слугувати одній граматичній темі, яка вивчається на цей момент. Навчальний текст має бути насиченим граматичним матеріалом, який закріплюється в діалогах, у монологічних висловлюваннях, як спонтанних, так і підготовлених.

Враховуючи початковий етап навчання, вивчення нової граматики починається зі спостереження й аналізу граматичного явища, фіксації висновків. Для демонстрації варто використовувати граматичні зразки з повсякденного спілкування та найпростіші приклади. У цьому випадку можна застосовувати індуктивний метод (від поодинокого до загального), запропонувати проаналізувати таблицю 3 прикладами, зафіксувати висновок (Капітонова, 2006: 137).

Вивчення, закріплення, впровадження граматичного явища в активну мовну практику слухачів відбувається за допомогою ретельно підібраної системи вправ - від підготовчих до мовленнєвих. Провідні методисти в галузі викладання іноземних мов говорять не про окремі вправи, а саме про систему вправ. «Зараз стає очевидним, що створення саме системи вправ, які відповідають меті й умо- 
вам навчання, є завданням номер один у методичній науці» (Вохмина, 1993: 95). Розв’ язати це завдання допомагає шестистадійна модель системи вправ, яку запропонував Є.I. Пассов: 1) сприйняття структури; 2) імітація; 3) підставлення; 4) трансформація; 5) цілеспрямоване ізольоване використання (генералізація); 6) перемикання 3 моделі на модель (Пассов, 1997: 57).

Так, коли на початковому етапі в четвертому модулі слухачі знайомляться 3 категорією числа (одниною і множиною), розділ 3 додаткових матеріалів і тренувальних вправ (Богиня, 2021: 9) пропонує спочатку таблиці чоловічого, жіночого, середнього роду однини і множини (студент - студенти; студентка - студентки; вікно - вікна). Значну увагу варто приділити виняткам для запам'ятовування, в яких дібрані найуживаніші слова тільки однини й тільки множини. Виконання тренувальних вправ, де треба писати за зразком слова в множині (ручка - ручки), потім - за зразком слова в однині (ручки - ручка), потім - словосполучення (ручка і зошит - ручки і зошити), речення - (Це зошит. - Це зошити.), закріплює вживання категорії однини та множини в мовній нормі. Далі виконуються вправи на норму і виняток. За такою ж або подібною схемою відпрацьовується кожна граматична категорія.

На певному етапі навчання у вправах доцільно використовувати як лексику нейтрального стилю мови, так і лексику наукового стилю мови, оскільки автоматично такі навички не переносяться. На наш погляд, такий матеріал варто запропонувати не в межах одного виду вправ, а чітко диференціювати. Є.I. Пассов називає таке виконання вправ «спеціально організованою і спрямованою діяльністю, яка досягає позитивних результатів» (Пассов, 1997: 59).

Досліджуючи методику викладання іноземної мови останніх років, викладачі навчальнонаукового центру 3 підготовки іноземних громадян ПДМУ працюють над укладанням навчальних посібників з української мови для іноземних слухачів, де розробляють вправи, спрямовані на формування навичок у всіх видах мовленнєвої діяльності: читання, говоріння, аудіювання і письмо. Експериментальні посібники проходять апробацію під час навчального процесу в навчально-науковому центрі з підготовки іноземних громадян, видаються, а потім упроваджуються в навчальний процес.

Один із таких посібників - «Українська мова як іноземна» (автори Богиня Л.В., Горбенко Є.В., Савицька Т.В.) - складається із 12-ти розділів. У першому розділі містяться завдання, спрямовані на розвиток навичок вимови та читання на рівні складу слова, словосполучення, речення, мікротексту; розділи 2-10 містять довідкові матеріали й тренувальні вправи 3 початкового фонетико-граматичного курсу (категорії роду і числа іменників, відмінювання й часові форми дієслів, прислівники, особові й присвійні займенники, прикметники тощо) для формування й закріплення навичок використання базових граматичних категорій в усному і письмовому мовленні. Кожний розділ посібника має граматичні таблиці, які забезпечують принцип наочності навчання. Розділ 11 - повторювальний. Форма посібника допускає виконання деяких навчальних завдань безпосередньо на його сторінках, що сприяє раціональному використанню часу на уроці. У розділі 12 пропонуються діалоги й тексти для читання на основі комунікативних тем «Аудиторія. Урок», «Моя сім’я», «Мій друг» тощо. У додатку до навчального посібника наведено найуживаніші етикетні форми, а також лексичні одиниці базових тематичних блоків «Знайомство», «Родинні стосунки», «Лічба в українській мові», «Дні тижня, місяці, пори року», «Зовнішність. Частини тіла людини». Посібник може бути використаний як для аудиторної роботи в супроводі викладача, так і для самостійної аудиторної та позааудиторної роботи іноземних студентів (Богиня, 2021).

Висновки і перспективи подальших досліджень Таким чином, вивчаючи граматику української мови на ретельно підібраних матеріалах, іноземні громадяни мають змогу через мову осягати українську культуру. Все це в комплексі дає можливість іноземним слухачам володіти усною формою мовлення в межах основних комунікативних потреб у реальних ситуаціях повсякденного спілкування і підготуватися до вступу в заклади вищої освіти України за вибраним фахом. 


\section{ЛITЕРАТУРА:}

1. Богиня Л.В., Горбенко Є.В., Савицька Т.В. Українська мова як іноземна. Початковий фонетико-граматичний курс. Довідкові матеріали й тренувальні вправи ; навчальний посібник для іноземних студентів. Полтава : Українська медична стоматологічна академія, 2021. $120 \mathrm{c}$.

2. Бойд Б. Владимир Набоков: Американские годы. Биография. Москва : Изд. «Независимая газета», 2004. $530 \mathrm{c}$.

3. Выготский Л.С. Мышление и речь. Москва : Лабиринт, 1996. 416 с.

4. Вохмина Л.Л. Хочешь говорить - говори. Москва : Русский язык, 1993. 235 с.

5. Ильин И.А. О сущности правосознания. Москва : Рарогь, 1993. 235 с.

6. Капитонова Т.И., Московкин Л.В. Методика обучения русскому языку как иностранному на этапе довузовской подготовки. Санкт-Петербург : Златоуст, 2006. 287 с.

7. Мова для всіх : навчальний посібник з української мови для іноземних студентів підготовчого факультету / укл. Н.С. Моргунова, О.О. Резван. Харків, ХНАДУ, 2007. Ч. 182 с.

8. Пассов Е.И. Основы методики обучения иностранным языкам. Москва : Русский язык, 1977. 276 с.

9. Чомски Н. Язык и мышление / перевод с анг. Б.Ю. Городецкого. Москва : МГУ, 1972. 123 с.

10. Щерба Л.В. Преподавание языков в средней школе. Общие вопросы методики. Изд. 2-е. Москва : Высшая школа, 1974. 112 c.

\section{REFERENCES:}

1. Bohynia L.V., Horbenko Ye.V., Savytska T.V. (2021). Ukrainska mova yak inozemna. [Ukrainian as a foreign language]. Pochatkovyi fonetyko-hramatychnyi kurs. Dovidkovi materialy y trenuvalni vpravy. Navchalnyi posibnyk dlia inozemnykh studentiv. Poltava: Ukrainska medychna stomatolohichna akademiia. 120 p. (in Ukrainian).

2. Boyd B. (2004). Vladimir Nabokov: Amerikanskie godyi. Biohrafiya. [Vladimir Nabokov: The American Years. Biography]. Moskva: Izd. «Nezavisimaya gazeta». 530 p. (in Russian).

3. Vyigotskiy L.S. (1996). Myishlenie i rech. [Thinking and speech]. Moskva: Labyrynt, 416 p. (in Russian).

4. Vohmina L.L. (1993). Hochesh govorit - govori. [If you want to talk, talk]. Moskva: Russkiy yazyik. 235 p. (in Russian).

5. Ilin I. A. (1993). O suschnosti pravosoznaniya. [About the essence of legal consciousness]. Moskva. $235 \mathrm{p}$. (in Russian).

6. Kapitonova T.I., Moskovkin L.V. (2006). Metodika obucheniya russkomu yaziku kak inostrannomu na etape dovuzovskoy podgotovki. [Methods of teaching Russian as a foreign language at the stage of pre-university training]. $\mathrm{S} .-\mathrm{Pb}$.: Zlatoust, (in Russian).

7. Mova dlia vsikh. [Language for everyone]. Navchalnyi posibnyk z ukrainskoi movy dlia inozemnykh studentiv pidhotovchoho fakultetu Chastyna 1 / ukl. N.S. Morhunova, O.O.Rezvan. Kharkiv, KhNADU, 2007. 82 p.

8. Passov E.I. (1977). Osnovyi metodiki obucheniya inostrannyim yazyikam. [Fundamentals of methods of teaching foreign languages]. Moskva: Russkiy yazyik. 276 p. (in Russian).

9. Chomski N. (1972). Yazyik i myishlenie. [Language and thinking] / perevod s ang. B.Yu. Gorodetskogo. Moskva: MGU. 123 p. (in Russian).

10. Scherba L.V. (1974). Prepodavanie yazyikov v sredney shkole. [Language Teaching in Secondary School]. Moskva.: Vyisshaya shkola. 112 p. (in Russian) 